\title{
Ethics and Accountability in Public Service of Nigeria: The Obligation Theory Perspective
}

\author{
Victor Mkuma Bem \\ Registry Department, University of Agriculture Makurdi PMB2373 Benue State-Nigeria.
}

\begin{abstract}
This study sought to establish the practicability and extent to which Ethics and Accountant ability ethos are entrenched in the Nigerian Public Service, with the view to ascertaining the level to which the country's development is affected positively or negatively. In this regard secondary data by way of content analysis was extensively used. Personal observation also contributed to the study. The study found that adequate mechanisms and infrastructure has been put in place to facilitate Ethical and Accountability standards in the Nigerian Public Service, but without achieving envisaged results. The Service therefore is not transparent in its conduct and consequently exhibit high level corruption. It is therefore suggested that moral tuition and enlightenment campaigns be carried out to ensure that good leaders are elected, in order to also develop the political will to enforce sanctions against misconduct in the service, thereby enhancing general societal development.
\end{abstract}

\section{Introduction}

Ethics and Accountability are interrelated and or twin concepts which generally seek to safeguard the conduct of organizations and society to achieve the desired human development. In public Service Ethics and Accountability principles are enshrined in the rules and regulations to ensure proper conduct of officials, corporate bodies and government organs, to facilitate efficient service delivery which should translate to societal development. Ethics and Accountability therefore places an obligation on the Nigerian Public Service (Officials and Elected/Political appointees) to serve in a manner as to ensure the wellbeing of the citizenry as well as societal development, and this informs the basis of this paper.

\section{Conceptual Clarifications}

Ethics: This is a branch of Philosophy which specifically seeks to address Morality. In the Public Service, Ethics focuses on the fundamental premise of Public Administrators duty as a steward to the public.(en.wikidepia.org/wiki/Ethics in Public administration 2013) Suffice to say that Ethics serves as moral justification and considerations for decisions and actions made during the completion of duties when working to provide general services of Government and Non Governmental Organizations. It thus provides accountability standards by which the public will scrutinize the work being conducted by members of these organizations.

Accountability: This concept in Public Administration entails answerability, blameworthiness, liability and expectation of account giving (Dyskta 1939). He further sees Accountability as a task to acknowledge and assume responsibility for actions, products, decisions and policies including administrative governance and encompassing the obligation to report, explain and be answerable for resulting consequences.

Accountability therefore places moral obligation on leadership and the led in Government operations. According to Amanda (1992), it is to be seen as an account giving relationship between individuals, where as individual $\mathrm{A}$ is obliged to inform individual $\mathrm{B}$ of his or her past or intended actions and decisions to justify them and suffer punishment in the case of established misconduct.

\section{Symptoms of Unethical and Non Accountability Practices}

The Public Sector globally is established to be built on Ethical codes and accountability principles. In Nigeria, the Constitution has prescribed ethical codes that would make the Public servants accountable to the public and Society at large. It infers that negative consequences may become pronounced as a result of unethical conduct or non accountability practices in the Nigerian Public sector. These consequences usually would manifest as high scale corruption, which impedes economic development, undermines stability and erodes trust in Public institutions. There is also generally lack of poor quality of essential public infrastructure and services which are borne by the poor. Nigeria no doubt exhibits these features. This is an indication that there is an endemic problem with Nigerian society which could be rightly argued to be reflection of several other societies. This paper shall therefore address the issue of reoccurring unethical cum non accountability practices as well as how the Nigerian Public Sector could be managed to ensure transparency and accountability. 
From the foregoing therefore the focus of this paper is to determine the cause of unethical conduct and also to find out whether the Nigerian Public Sector is being managed transparently or not. The methodology used is content analysis and personal observation.

\section{Contexting the Nigerian Public Service within the framework of Rollin Van Broekhovens' Obligation Theory}

Broekhoven(2010), postulated the obligation theory which is found adequate for addressing issues of Ethical and Accountability practices in Public Service. He opined that three issues are basically involved in analyzing Ethics and Accountability. The first is the obligation an individual has in taking decision on the basis of moral evaluation of what is right or wrong or obligatory permissible or forbidden. This he stated allows individuals and organizations to make a moral judgment of arising issues. Secondly and as colloraly, it involves valuing of the choices made. The right or obligatory choice made has a worth. There ought to be a relationship between the values one holds and decision made, as it answers the question of what makes something good or valuable. Thirdly, is the issue of motivation? What should be the thought of employees (Public Servants) or individuals as they perform their tasks? Self interest may lead one to value highly something that may not be valuable to the generality of the people, which also hinders accountability.

In line with these postulations, the Nigerian Constitution places the government under obligation to meet the needs of the people and enhance their wellbeing.(Tokumboh 1990). The Public Servants who are implementers of the government policy are equally under obligation to serve the people right. The Nigerian Public Service also provides guidelines to Public Servants to evaluate choices, decide on what is good or permissible, to implement policies in a manner that good governance is enhanced and the well being of the people guaranteed. By these provisions the conduct of the Public servants ought to be regimented for the general good, and if found deviating or wanting in any area, the resulting consequences expressed as corruption and the associated ills are subjected to prescribed punishments.

In spite of the foregoing, it has been established that lack of transparency and corruption still thrive on a high scale in Nigeria and elsewhere in the world thereby thwarting development, despite the huge sums of monies committed by governments world over to tackle the world's most pressing problem. The 2010 Corruption Perception Index (CPI) updated in 2013 shows that nearly three quarters of the 178 countries in the Index score below five on a scale from 10 (very clean) to 0 (highly corrupt), which indicate a serious corruption level(CPI 2010). Nigeria ranked position 134 with a score of 2.2 indicating that it is highly corrupt, which again is a confirmation that the Nigerian Public Service is very much encumbered by unethical and non accountability practices. In other words choices made are not in the interest of the generality of the people or are not what is permissible. This results to unethical conduct. Thus corruption is one symptom of poor administration and management, which allows unscrupulous public officials to exploit the opportunity for putting self above Public interest contrary to Public Service detects.

The Division of Public Administration Development Management (DPADM) in recognition of the serious challenge to global development sought out to support setting institutional standards, carrying out policy analysis and assisting in building capacity institutions to save guard public sector Ethics, transparency and accountability. The DPADM also preserves activities of other Public officials by putting in place Ethics infrastructure that not only provide guidance for good conduct but also administratively and legally punishes misconduct. Similar such activities have been undertaken in Nigeria to ensure that the Public Service understand its obligations to the public and is properly guided to judge appropriately in determining what is good or permissible, correct valuing of choices and thinking only of public interest as choices are being considered. Such infrastructure include the Departmental circulars, Civil Service Rules, Financial Regulations and currently due process as well the institutions such as Code of Conduct Bureau (CCB),Independent Corrupt Practices Commission (ICPC) and Economic and Financial Crimes Commission(EFCC) established to ensure ethical conduct, transparency and accountability in the Nigerian Public Service .

The Nigerian society has however been adjudged to have remained underdeveloped courtesy of a corrupt Public Service. The failure of such mechanisms to achieve envisaged results could be attributed to obvious reasons of double standards fuelled by selfish interests. For instance, it is argued that the institutions established to fight corruption and similar other vices in the service could not achieve results because such institutions are known to be used selectively in fighting perceived enemies (Haruna 2013). Another scholar Azeez (2013), contend that the failure of Nigeria to overcome the evil of corruption and by extension poverty which are byproducts of unethical cum non accountability practices is largely due to ignorance entrenched to keep Nigerians perpetually poor for corruption to thrive. This situation is observed to be even worse during civilian regimes which ironically operate with constitution as against decrees as in military regimes and which should be more civic and upright in conduct. Haruna (2013) again confirmed that African leaders especially the civilians never practiced the virtues they preached. He specifically cited the case of Nigeria, where between 1999-2007, Nigeria got more revenue from oil but instead experienced greater infrastructural decay in spite of 
the condemnation of previous regimes for their inability to develop the Nigerian society. Suffice to say that unethical and non accountability practices in Nigeria continued unabated, there by entrenching corruption deeper, resulting to greater poverty in the country.

\section{Conclusion and Recommendation}

In conclusion therefore, it is established that there is corruption and lack of transparency in Nigerian Public service occasioned by unethical practices and lack of accountability in spite of the institutional mechanism and accountability infrastructure developed to ensure efficient service delivery and consequent societal development. It is therefore pertinent to suggest that the issue of moral tuition in Nigeria should be taken seriously. Such will not only awaken the conscience of Nigerians to ensure that good leaders who will lead by example are elected, but will also ensure proper conduct of public affairs. The leaders in such circumstance will no doubt develop the political will to enforce sanctions against unethical conduct to stimulate the desired accelerated development in Nigeria.

\section{References}

[1] Amanda, S(1992)The Chameleon of Accountability, University Meiboune, Graduate School of Management 1992

[2] Toumboh, M.A (1990) Public Enterprises; the Nigerian Experience. Latern Books Lagos Nigeria

[3] Dyskta, C.A “The Quest for Responsibility" American Political Science Review journal Volume 33No.1 February 1939

[4] Corruption Perception Index Report (2013 Ed)

[5] Haruna, M. "On Ethics and Leadership in Africa II"( Daily Trust July 10, 2013.Published by Media Trust Limited)

[6] Vandrokhoven Rollins dogspot.com Theory of Obligation 2010

[7] Azeez, T. (2013) "Poverty and bad Governance; A Political viscious circle. (A paper presented at the Professional Induction Course of The West the Society for Communication Administration-WASCA), held on $6^{\text {th }}$ July 2013 at West Point Hotel, Abuja 